Failing in this, with a dexterity worthy of the Knight of the Shears it cut the worm in two, letting about three-fourths of it fall to the ground. The remainder was then easily dragged to the surface of the leaf, where the wasp spent some fifteen minutes in cutting down, trimming, and reducing it to a globular mass of about an eighth of an inch in diameter. Then resting for a few minutes, and taking a fresh hild of its booty, it flew briskly away.

Lyons, N.Y., August I3 J. T. BROWNELL

\section{Treatment of Hay Fever}

Some years ago Prcf. Helmholtz, in a letter to you, gave an account of a remedy he had found for "hay fever." This was simply to treat the part of the nose, which seems to be the seat of the trouble, with sulphate of quinine solution by pouring it into the nose with a pipette, while lying on a sofa with the head turned upside down. Having had the most enjoyable part of summer destroyed by hay fever ever since I can remember, I have tried every remedy $I$ have beard of, including internal doses of arsenic, and I have found them all to fail. Prof. Helmholtz's method only gives me relief for ten minutes or sc, and cold wate does the same. I have tried solutions of sulphate of zinc and tannin, and many other astringents, but all to no purpose. As many others knew that I was experimenting upon myself in this matter, I have had several patients trying all the remedies that I have tried, and I can therefore say with cerlainty that no remedy yet published will cure hay fever. I have however succeeded in finding a method which is a really effectual cure, and as I know that many are rendered miserable during the most enjoyable part of the year, I hasten to give them the benefit of the result of my inquiries. One thing which misled me was that my eyes were often very much inflan:ed and pained during an attack, and I often tried remedies for my eyes (which have sometimes gone wrong when I had no hay fever) when they were only affected in sympathy with my nose. I found that the only thing required was to prevent the entrance of the pollen grains into the nose. When there are not many in the air, as during or after rain, it is simply necessary to stop the nose with a spring clip. I have used a piece of brass or steel ribbon bent dcuble, and having only sufficient spring to close the nostrils without undue pressure. This causes the patient to breathe by the mouth, but one soon gets accustomed to the inconvenience. I found that to stop the nostrils with cotton wool was far too irritating, especially as those afflicted with hay fever are so owing to the tenderness of the internal coating of the $\mathrm{n}$ cse. When going amongst hay a further precaution must be taken, viz., plugging the ducts from the eyes. I used for this purfose dumb-bell shaped pieces of glass, which are easily slipped into the ducts, and can be removed when wanted. Thus protected, any one who is troubled by hay fever can go into the camp of the enemy and stir up hay in a field with as much impunity as one not troubled with this "sixth sense." The season for hay fever is nearly passed now, but I hope that the publication of this note will be the cause of relief to many during next summer, and on that plea I ask its publication in your valuable journal, and I hope that medical men in the South of England, where hay fever is common, will give it a trial and report upon it next summer. In Scotland hay fever is practically unknown.

Cove Castle, Loch Long, N.B.

\section{Red Rainbows}

Prof. S. P. Thompson's letter (p. 459) makes me recall that when on September 2 last year I crossed Wales westwardly from Hereford, on a fine sunny day, the train ran into a misty :hower after 6 p.m. at Machynlleth, and out of it as we neared the viaduct at Barmonth. The sun had been obscured for some time, when it suddenly shone out through a chink between sea and cloud, causing in the east a very beautiful red rainbow. Like Prof. Thompson, I was under the impression that the phenomenon was of no uncommon occurrence, so did nothing more than note it in my diary.

Cambuslang, September 16

\section{Infusorial Parasites on Stickleback}

ONE day in June, when examining a very small stickleback under the microscope, I was surprised to find it infested by numbers of infusoria, evidently parasitic upon it. This led me to examine others from the same water, viz, a pond very rich in infusorial life generally, as also specimens from the river close at hand. Every specimen from the pond was similarly attacked, while none of those from the river were so. The parasite is apparently Trichodina pediculus, which is stated to be parasitic upon Hydra vulgaris. Want of literature on the subject bas prevented me from following the matter up, but it seems that I have found, if not a new species, at least a new host for a known species. I sball be glad if any of the readers of NATURE can give me any information on the subject.

N. H. POOLE

Charterhouse, Godalming

\section{Photographing Diffraction Rings-Optical Phenomenon}

THE peculiar character of the photographs of an opening to the sky in the dark Cyclopean gallery at Tiryns, to which $\mathrm{Mr}$. W. J Stillman calls attention (NATURE, vol. xxiv. p. 260), finds an obvious explanation in the well-known optical phenomenon of diffraction rings, produced when a beam of light is transmitted through a small circular aperture, and viewed by means of a lens. Had your "Cecropian" correspondent examined the image of the illuminated opening by the assistance of a lens, the phenomenon of concentric coloured rings would, doubtless, have been recognisable to the eye. Hence the only point of interest in the phenomenon observed by Mr. Stillman is the significant fact that in securing the fleeting images of the rings on the gelatine plate-the actinic rays being alone effective-alternate dark and bright concentric rings are produced, as in the case of homogeneous or monochromatic light, instead of the coloured rings seen by interposing a lens between the aperture and the eye. In other terms, the impressions on the gelatine plate being due to the action of the monochromatic actinic rays, the theory of diffraction shows that the concentric rings should be alternately dark and bright. This is an important circumstance in the applications of photography to such investigations.

Berkeley, California, August 16 JoHn Le Conte

\section{A Primitive Diving-Bell}

In Nature, vol. xxiv. p. 20r, it is stated that Herr Budde has found a description of a primitive diving-bell in a work of Bartolini, 1674. The inventor appears to have been Franciscus Kesler, 1616. This description of Kesler's diving machine will also be found, together with representations of the same, in Schwenter's "Deliciæ Phy ico-Mathematicæ," I636, a very rare and curious volume; so rare indeed that it is stated in Cosmos, January 27,1860 , "it is not to 1 e found in the Imperial Library, nor in any of the cublic libraries of Paris." J. van Lennep, in Notes and Queries, December 15, 1859, p. 503, says "there is a Dutch translation of Schwenter, .1672 ; of this rare volume I fortunately possess a copy."

Sidmouth, September I I

ITtavio LAUDI.-Messrs. Truibner, publishers, Lcndon, might be able to help you to get copies of the Chinese translations mentioned in Mr. Fryer's articles on "Science in China."

FREDERICK CURREY,M.A., F.R.S.

THE late Frederick Currey, whose death was announced in last week's NATURE, p. 475, was born at Eltham on August 4, 1819 , educated at Eton and Trinity College, Cambridge, there obtaining a scholarship, and attaining his B.A. in I84I ; three years later he proceeded to M.A., and was called to the Bar, afterwards practising as conveyancer and equity draughtsman.

His first public performance as a scientifie writer was a translation of Schach's "Das Mikroskop" in 1853 , a second edition of which was called for within two years. In the Microscopical Fournal for 1854 he published some observations on two new fungi, and by the same channel he afterwards communicated several papers, chiefly on the obscure points in the reproduction of the lower cryptogams. The Greenwich Natural History Club was established in $185^{2}$, Mr. Currey being one of the earliest members, and the next year he read a paper on the 
"Fungi of the Neighbourhood of Greenwich," which was printed in the fifth volume of the Phytologist. In 1857 a committee of that Club was appointed to draw up a report on the flora of the district; Mr. Currey was chosen its chairman, and drafted the report, which enumerated 395 fungi. In that year he contributed a paper to the Royal Society, which was printed in the Proceedings, On the Occurrence of Amorphous Starch in a Tuberaceous Fungus, a point of much interest, as starch is rarely found in fungi. $\mathrm{He}$ was elected Fellow of the Linnean Society in 1856 , and in 1858 Fellow of the Royal Society also; in 1860 he was appointed secretary of the former society in succession to Mr. J. J. Bennett, a post which he held until 1880 , when he relinquished that office and acceded to the less arduous duties of treasurer, retaining that appointment until his death. In 1862 the Ray Society issued a translation, with considerable additions, from Hofmeister, entitled "On the Germination, Development, and Fructification of the Higher Cryptogamia," a task which Mr. Currey undertook in 1859; the following year he edited a second edition of Dr. Badham's "Esculent Funguses of England," in which he made as few alterations as possible. Several papers on mycological subjects appear in the Transactions of the Linnean Society, which will be found in the "Catalogue of Scientific Papers," under his name, his last contribution being, "On a Collection of Fungi made by Mr. Sulpiz Kurz," in 1876.

By his death the Linnean Society has lost an experienced officer, and its members a valued friend whose place it will be hard to fill.

\section{THE AMERICAN ASSOCIATION}

THE thirtieth meeting of the American Association for the Advancement of Science commenced at Cincinnati on August I6. Always a hot place in summer, the temperature at Cincinnati during the past two months has been at intervals unusually high, running above $100^{\circ}$ for several days together. This and the fear of its recurrence no doubt induced many to stay away who would otherwise have been present. However, a goodly number - over 400-of new members were enrolled, and many papers of interest were read. Some of the visitors from the Eastern States were amazed to find that Cincinnati was not a little backwoods town, but a city deserving in many ways the title she claims, "The Queen City of the West." The ignorance of many of the inhabitants of the Eastern States in regard to the West is only equalled by the ignorance of Europeans in regard to America generally.

The citizens of Cincinnati exerted themselves to welcome their guests, and did it well. Their bodily wants were amply supplied, and this, to those coming from a distance and being strangers, was a matter of no small moment. Visitors knowri or bearing introductions were in very many cases entertained privately, and a free lunch was provided by subscription for all members daily from I to 2.30 p.m. The Western Union Telegraph Compariy, whose wires extend over almost the whole Union, gave the members the use of their lines for communication with their families, free of charge, at whatever distance they might be situated. Con nection was made by telephone between the hall of meeting and the Central Telegraph Office, and between the various rooms in the building, so that it was possible to send a message without leaving the building-to ask, for example, what paper was being read in any other section. The City and Suburban Telegraph and Telephone Companies also extended the same privileges to members of the Association. The various Express Companies offered to convey light parcels containing specimens for them, free of charge, between their homes and the place of meeting, and heavy ones at low rates. Of course there was a post-office and a parcels office in the hall, with convenience and materials for writing. There was however a little deficiency in finger placards to direct strangers over the great building in which the meetings were held - the new music hall.

Besides the above, an excursion was arranged for Saturday afternoon to the Zoological Garden, one of the best in the country, and capable, if well supported, of becoming the best. Free transportation through the streets by the horse cars was provided, and a sumptuous repast prepared for the visitors before leaving. In the same way the Anthropological Section and others were taken out to Madisonville, about ten miles from the city, on Monday to see a prehistoric cemetery recently discovered, from which several hundred skeletons, uncounted arrowpoints, animal bones, horns, and teeth, and pieces of pottery have been exhumed during the past two years. The train stopped at the place to set them down, and again on its return to take them up. After the adjournment of the meeting an excursion was arranged to the Mammoth Cave, about 150 miles distant, and another to Chattanooga, about 300 miles over the new Southern Railway, both free so far as the travelling was concerned.

It will be evident that Cincinnati did her best to entertain her scientific visitors, and the latter carried away pleasant and lasting impressions of the city where the fifth and the thirtieth meetings of the Association were held, the latter having been one of the most successful in its history.

E. W. Claypole

\section{Another correspondent writes :-}

The Cincinnati meeting proved to be one of the best ever held by the Association. In attendance of members it was much surpassed by the Boston meeting last year, which reached the phenomenal number of 997 ; the number at Cincinnati was about 550 , being more than double that at any previous meeting in the West. Over 400 persons joined the Association. Nearly 200 papers were presented ; it is not derogatory to any author to say that these papers were of average interest only, and comprised no startling announcements. The general management was very successful. The chief feature of the meeting was the adoption of the important changes in the constitution which are expected to simplify business in the future. If any complaint can be made, it is of the rather generous disposition on the part of the Sectional Committees towards authors whose productions are of doubtful novelty and uncertain value. There is a tendency also to overrun the allotted time; papers for which twenty-five minutes are asked consume seventy minutes, and those of ten minutes extend to thirty minutes. The remedy of this evil lies with the chairmen of the sections, and it is hoped that they will hereafter exert their powers more frequently. The social features of the meeting were very enjoyable ; the reception at Highland House, and the daily lunches served in the Exhibition building brought together citizens and members in pleasant intercourse.

Prof. Wm. B. Rogers of Boston, the first presiding officer of the Association, was elected an Honorary Fellow, on the unanimous recommendation of both Sections $\mathrm{A}$ and B. Prof. Rogers is the first Honorary Fellow chosen by the Association.

The amendments to the constitution proposed at the Boston meeting were adopted almost unanimously. They provide for the formation of nine sections, as follows :-A, Mathematics and Astronomy ; B, Physics; C, Chemistry; D, Mechanical Science; E, Geology and Geography ; F, Biology; G, Histology and Microscopy; $\mathrm{H}$, Anthropology; I, Economic Science and Statistics.

Each of the above Sections is to have its own chairman, who is also Vice-President of the Society, and its own Secretary. The amended constitution also creates the office of Assistant-General Secretary, makes certain changes in the composition of the Standing Committee, 